\title{
Confiabilidade do instrumento de avaliação da prontidão do prematuro para alimentação oral $* * * *$
}

\author{
Reliability of an instrument to assess the readiness of preterm infants \\ for oral feeding
}

\author{
Cristina Ide Fujinaga* \\ Nelma Ellen Zamberlan** \\ Milena Domingos de Oliveira Rodarte** \\ Carmen Gracinda Silvan Scochi***
}

\begin{abstract}
* Fonoaudióloga. Doutora em Enfermagem em Saúde Pública. Professora Adjunta I da Universidade Estadual do Centro-Oeste (PR). Endereço para correspondência: Rua Nossa Senhora de Fátima, 256 - Apto. 02 - Irati - PR - CEP 84500-000 (cifujinaga@irati.unicentro.br).

**Fonoaudióloga. Doutoranda em Enfermagem em Saúde Pública - Escola de Enfermagem de Ribeirão Preto da Universidade de São Paulo.

***Enfermeira. Doutora em Enfermagem. Professora Titular da Escola de Enfermagem de Ribeirão Preto da Universidade de São Paulo.

*****Trabalho Realizado na Unidade de Cuidados Intermediários do Hospital de Clínicas da Faculdade de Medicina de Ribeirão Preto - Universidade de São Paulo.
\end{abstract}

Artigo de Pesquisa

Artigo Submetido a Avaliação por Pares

Conflito de Interesse: não

Recebido em 07.02.2007.

Revisado em 02.04.2007; 15.05.2007.

Aceito para Publicação em 17.05.2007.

\begin{abstract}
Background: the transition from gastric to oral feeding of preterm infants is one of the greatest concerns of health professionals and therefore needs an objective criterion to support the beginning of this process. Aim: to test the reliability of an instrument that assesses the readiness of preterm infants for the transition from gastric to oral feeding. Method: the instrument is composed by the following items: corrected gestational age; behavioral state; global posture and tonus; lips and tongue posture; rooting, suck, bite and gag reflexes; tongue and jaw movements; tongue cupping; sucking strain; sucking and pause; maintenance sucking/pause; maintenance alert state and stress signs. The study was conducted at the Intermediate Care Unit of the Hospital de Clínicas da Faculdade de Medicina de Ribeirão Preto - University of São Paulo. The research sample consisted of 30 preterm infants who attended the following inclusion criteria: corrected gestational age <36 weeks and 6 days; clinically stable; absence of facial deformities; respiratory, cardiovascular, gastrointestinal and neurological disorders or syndromes that prevent or make oral feeding difficult; and not having received oral feeding of milk. The Kappa Test was used to verify interjudge reliability. Results: the items that presented high reliability levels were: behavioral state, global posture and tonus, lips and tongue posture, gag reflex and maintenance of alert state. The items that presented satisfactory reliability levels were: rooting reflex, sucking and biting and jaw movement, sucking strain and sucking and pause. Only the items of tongue cupping, maintenance of sucking/pause and stress signs presented unsatisfactory reliability levels. Conclusion: in general, the items investigated by the assessment instrument presented adequate interjudge reliability.
\end{abstract}

Key Words: Premature Infant; Feeding Behavior, Reliability.

\section{Resumo}

Tema: a transição da alimentação gástrica para via oral do bebê pré-termo é uma das maiores preocupações da equipe de saúde que assiste a esta população e necessita de um critério objetivo que auxilie o início desta transição. Objetivo: testar a confiabilidade de um instrumento de avaliação da prontidão do bebê prematuro em iniciar a transição da alimentação gástrica para via oral. Método: o instrumento é constituído dos seguintes itens: idade corrigida; estado de consciência; postura e tônus global; postura dos lábios e língua; reflexo de procura, sucção, mordida e vômito; movimentação e canolamento de língua; movimentação de mandíbula; força de sucção; sucções por pausa; manutenção do ritmo de sucção por pausa; manutenção do estado alerta e sinais de estresse. $\mathrm{O}$ estudo foi realizado na Unidade de Cuidados Intermediários do Hospital de Clínicas da Faculdade de Medicina de Ribeirão Preto - Universidade de São Paulo e a amostra foi constituída de 30 bebês pré-termo que atenderam aos seguintes critérios de inclusão: idade gestacional corrigida menor ou igual a 36 semanas e 6 dias; clinicamente estáveis; ausência de deformidades faciais, distúrbios respiratórios, cardiovasculares, gastrointestinais e neurológicos ou síndromes que impedem ou dificultam a alimentação oral; e não terem recebido alimentação láctea por via oral. A confiabilidade foi determinada através aplicação do teste Kappa para verificar a concordância entre avaliadores. Resultados: os itens cujos valores atingiram concordância excelente foram: estado comportamental, postura e tônus global, postura de lábios e língua, reflexo de vômito e manutenção do estado alerta; os itens que atingiram concordância satisfatória: reflexo de procura, sucção e mordida, movimentação da mandíbula, força de sucção e sucção por pausa; apenas os itens canolamento de língua, manutenção da sucção por pausa e sinais de estresse atingiram concordância insatisfatória. Conclusão: de forma geral, os itens do instrumento apresentam confiabilidade adequada entre os observadores.

Palavras-Chave: Prematuro; Conduta na Alimentação; Confiabilidade.

Referenciar este material como:

FUJINAGA, C. I.; ZAMBERLAN, N. E.; RODARTE, M. D. O.; SCOCHI C. G. S. Reliability of an instrument to assess the readiness of preterm infants for oral feeding 53 (original title: Confiabilidade do instrumento de avaliação da prontidão do prematuro para alimentação oral). Pró-Fono Revista de Atualização Científica, Barueri (SP), v. 19, n. 2, p. 143-150, abr.-jun. 2007. 


\section{Introduction}

Neonatal Care has been transforming in recent year, mainly with respect to care humanization. The concern is to focus care not only on preterm infants' survival, but also to a comprehensive, humanized and preventive care, within an individualized and developmental care perspective (Byers, 2003), with a view to these children's quality of life (Scochi et al., 2003; Nascimento e Issler, 2004). This care reveals a tendency to offer mother's milk as early as possible, so as to meet infants' nutritional needs (Nascimento and Issler, 2003), to encourage breastfeeding (Rocha, Martinez and Jorge, 2002), to improve motherbaby relations (Delgado and Halpern, 2005) and to include the mother in care during the stay at the Neonatal Unit (Fonseca et al., 2004;), besides providing for the adequate development of oral functions (Byers, 2003, Sanches, 2004; Delgado and Halpern, 2005). Despite all of these benefits, there is a need to train the Neonatal Care team in terms of breastfeeding-related issues (Serra and Scochi, 2004).

In clinical practice, professionals face difficulties to precisely determine the ideal moment to start the transition from gastric to oral feeding. In general, the criteria to start this transition are weight and gestational age. In this process, most health professionals have only looked at isolated data for the infants, without an assessment that takes into account aspects of their general conditions, neuro-psychomotor development and oralmotor ability (Thoyre, 2003).

Moreover, at many neonatal units, pacifiers or bottles are used in this feeding transition (Howard et al., 2003; Lau, Smith and Schanler, 2003), as opposed to the benefits of breastfeeding over artificial feeding, due to the clinical risks infants using pacifiers or bottles are submitted to (Sanches, 2004; Andrade and Guedes, 2005).

The assessment of nonnutritive sucking can be used as one sign of maturity for the transition to oral feeding, together with other aspects of the infant's global behavior, such as gestational age, posture and global tonus and behavioral state (Pinelli, Symington and Ciliska, 2002; Caetano, Fujinaga and Scochi, 2003; Thoyre, 2003; Neiva and Leone, 2006).

Most scales assess preterm feeding through descriptive observation, using the
Neonatal Oral-Motor Assessment Scale (NOMAS). This scale consists of 13 characteristics of jaw movement and 13 characteristics of tongue movement, which are divided into categories of normal, disorganized and dysfunctional. The assessment of nonnutritive sucking takes 2 minutes and nutritive sucking 5 minutes (Palmer, 1993). An observation scale of premature infants' feeding pattern was developed to verify tolerance to oral milk intake, specifically looking at feeding-related abilities, such as oral-motor organization; coordination between the sucking, swallowing and breathing functions and clinical stability (Thoyre, Shaker and Pridham, 2005). However, Brazilian literature does not offer any protocols to assess premature infants' sucking which have been validated. This is a necessary aspect for a legitimate instrument.

An instrument to assess preterm infants' readiness for oral feeding and the respective instructional guide, including operational definitions for the items to be assessed, were developed and submitted to content and face validation by 15 examiners, with an agreement level of $85 \%$ of higher. This instruments contains the following items: corrected age, behavioral organization (behavioral state, global posture and tonus), oral posture (lips and tongue), oral reflexes (rooting, sucking, biting and gag) and nonnutritive sucking (tongue movement, tongue cupping, jaw movement, sucking strain, sucking and pause, maintenance of rhythm of sucking and pause, maintenance of state of alertness and stress signs) (Fujinaga, 2002).

As a part of the clinical validation of this instrument, this study aims to test its interrater reliability.

\section{Method}

The study was carried out at the Intermediary Care Unit of the University of São Paulo at Ribeirão Preto Medical School Hospital das Clínicas and approved by the institution's Research Ethics Committee (process No 6225/2003). The infants' mothers signed the Free and Informed Consent Term.

We tested the instrument's reliability by analyzing the level of agreement between the results attributed by two observers to one and the same infant, by means of the Kappa coefficient, which measures interrater 
agreement and corrects casual proportion. For qualitative analysis, Kappa values above 0.75 were considered as excellent agreement; between 0.40 and 0.75 as satisfactory and below 0.40 as unsatisfactory agreement (Fleiss, 1981). We considered p?0.01 as significant. Two trained oral therapists with experience in neonatology applied the instrument.

A pilot study of 10 infants allowed us to identify problems in operational definitions and the way of observance of infants' behavior. We changed some scale items for better understanding and clarity of operational definitions and observations of infants' behavior (Fujinaga, 2005). The changes were made in item descriptions (Attachment). This article does not include the results of the pilot study.

The sample consisted of 30 preterm infants born between March 2004 and April 2005, who attended to the following inclusion criteria were: corrected gestational age ? 36 weeks and 6 days; clinically; absence of facial deformities; respiratory, cardiovascular, gastrointestinal and neurological disorders or syndromes that impede or difficult oral feeding; and not having received oral feeding of milk. Gestational age was calculated by the medical team through Ballard's somatic assessment (Ballard, Novak and Driver, 1979).

The study subjects were 15 male and 15 female premature infants. The mean gestational age at birth was 32 weeks and 2 days and the mean corrected age 34 weeks and 2 days. Mean weight was 1470 grams and respiratory discomfort at birth was the clinical problem in $75 \%$ of cases. Table 1 presents data for the infants in this study.

To apply the scale, two oral therapists assessed each infant 15 minutes before their feeding time. The order of assessment alternated between the two therapists. Although the assessment occurred simultaneously in each baby, the observers had no verbal contact.

Inside the incubator, the infant was assessed in a flexed lateral decubitus position of the lower and upper limbs and aligned head. The first observer stimulated the infant to wake up, using auditory, visual and tactile stimuli. This observer manipulated the infant to verify behavioral organization, oral posture and presence of oral rooting and vomiting reflexes. Both examiners simultaneously observed these behaviors.

The biting and sucking reflexes and nonnutritive sucking were assessed twice, once by each examiner, by means of the gloved little finger. Nonnutritive sucking was evaluated during 1 minute.

\section{Results}

Table 2 shows the Kappa $(\mathrm{K})$ results for each item and the qualitative assessment of the agreement results.

Seven $(41.2 \%)$ items revealed excellent agreement, $7(41.2 \%)$ satisfactory and only 3 $(17.6 \%)$ unsatisfactory agreement. 
TABLE 1. Infants' identification data

\begin{tabular}{|c|c|c|c|c|c|c|c|}
\hline Infants & Sex & Gestational Age & $\begin{array}{c}\text { Corrected Gestational } \\
\text { Age }\end{array}$ & $\begin{array}{c}\text { Days of } \\
\text { life }\end{array}$ & $\begin{array}{c}\text { Birth } \\
\text { weights }\end{array}$ & $\begin{array}{c}\text { Current } \\
\text { weight }\end{array}$ & Problems at birth \\
\hline 1 & Female & 36weeks & 36weeks1day & 1 & 1555 & 1555 & None \\
\hline 3 & Male & 31weeks5days & 33weeks4days & 11 & 1380 & 1365 & Respiratory discomfort \\
\hline 4 & Male & 27 weeks & 29weeks2days & 16 & 1005 & 1040 & Respiratory discomfort \\
\hline 5 & Male & 32weeks 3days & 34weeks2days & 13 & 1405 & 1450 & Respiratory discomfort \\
\hline 8 & Female & 33 weeks2days & 33weeks3days & 1 & 1700 & 1700 & None \\
\hline 9 & Female & 31weeks & 32 weeks & 7 & 1390 & 1255 & Respiratory discomfort \\
\hline 10 & Female & 33 weeks4days & 35 weeks1day & 11 & 1220 & 1250 & Respiratory discomfort \\
\hline 11 & Male & 32weeks & 34weeks2days & 9 & 1420 & 1365 & Respiratory discomfort \\
\hline 12 & Female & 34weeks2days & 36weeks & 11 & 1520 & 1445 & Respiratory discomfort \\
\hline 13 & Female & 30weeks6days & 32weeks6days & 14 & 1705 & 1900 & Respiratory discomfort \\
\hline 17 & Male & 32 weeks & 34weeks2days & 16 & 940 & 1059 & Respiratory discomfort \\
\hline 18 & Female & 33 weeks2days & 34weeks3days & 8 & 1180 & 1120 & Respiratory discomfort \\
\hline 19 & Male & 32weeks & 33weeks & 7 & 1670 & 1680 & Respiratory discomfort \\
\hline 20 & Male & 33 weeks2days & 33weeks6days & 4 & 1480 & 1450 & None \\
\hline 21 & Female & 32weeks & 35 weeks2days & 22 & 995 & 1114 & Respiratory discomfort \\
\hline 22 & Male & 34weeks3days & 36weeks2days & 13 & 1310 & 1330 & Apnea \\
\hline 23 & Male & 36weeks & 36weeks3days & 3 & 2400 & 2160 & Respiratory discomfort \\
\hline 24 & Male & 31 weeks4days & 34weeks2days & 19 & 1580 & 1615 & Respiratory discomfort \\
\hline 25 & Male & 33 weeks6days & 34weeks & 1 & 1880 & 1880 & None \\
\hline 26 & Female & 32 weeks2days & 36weeks1day & 27 & 1265 & 1405 & None \\
\hline 27 & Male & 32weeks & 32weeks1day & 1 & 1865 & 1865 & Respiratory discomfort \\
\hline 28 & Male & 34weeks3days & 35 weeks6days & 10 & 1375 & 1345 & Respiratory discomfort \\
\hline
\end{tabular}

TABLE 2. Inter-rater agreement - Kappa (K) on Preterm Infant Oral Feeding Readiness Assessment Scale items for 30 infants.

\begin{tabular}{lcc}
\hline \multicolumn{1}{c}{ Scale items } & Kappa & $\begin{array}{c}\text { Qualitative } \\
\text { assessment }\end{array}$ \\
\hline Behavioral state & 0.87 & Excellent \\
Global posture & 1.00 & Excellent \\
Global tonus & 1.00 & Excellent \\
Lips posture & 1.00 & Excellent \\
Tongue posture & 1.00 & Excellent \\
Rooting reflex & 0.59 & Satisfactory \\
Sucking reflex & $* 0.73$ & Satisfactory \\
Biting reflex & 0.65 & Satisfactory \\
Gag reflex & $* 0.79$ & Excellent \\
Tongue movement & 0.63 & Satisfactory \\
Tongue cupping & 0.19 & Unsatisfactory \\
Jaw movement & 0.53 & Satisfactory \\
Sucking strain & 0.60 & Satisfactory \\
Sucking and pause & 0.48 & Satisfactory \\
Maintenance of sucking/pause & 0.31 & Unsatisfactory \\
Maintenance of alert state & 0.87 & Excellent \\
Stress signs & 0.36 & Unsatisfactory \\
\hline
\end{tabular}

* Kappa Syntax 


\section{Discussion}

We did not find any research using a standardized protocol to determine readiness for transition to oral feeding, nor how this transition occurs (Caetano, Fujinaga and Scochi, 2003). There is a need for prospective studies to describe behaviors and physiological variables of preterm infants' ability to initiate and continue oral feeding (Thoyre, 2003).

The instrument described here can be used to evaluate preterm infants' readiness for oral feeding, as interrater reliability scores for most items were good, with a general Kappa agreement coefficient $>0.48$. Exceptions were tongue cupping, maintenance of the rhythm of sucking per pause and stress signs.

Tongue cupping is the elevation of tongue sides and the presence of a groove in the central region (Fujinaga, 2005) and is related to feeding efficiency. The low level of interobserver agreement may be due to measuring difficulties, as it depends on tactile sensitivity and is thus rather subjective.

Direct observation of infants' oral behavior is frequently used for evaluating sucking performance (Nyqvist et al., 2001), but the reliability of clinical observation has to be tested in comparison with objective exams, such as ultrasound imaging and electromyography.

Tongue elevation and sounds have been observed during nonnutritive sucking (Bulock, Woolridga and Baum, 1990), and tongue and hyoid bone movements during nutritive sucking, using bottles, and during nonnutritive sucking using pacifiers (Miller and Kang, 2007) by means of ultrasound imaging. However, the cupping movement has not been mentioned during sucking. Inside the uterus, the cupping movement has been observed during amniotic fluid sucking of healthy fetuses with average gestational age of 24 weeks and 3 days. Images were videotaped and analyzed by two observers, with Pearson's R=0.82 (Miller, Sonies and Macedônia, 2003).
We highlight the need for other studies to test the agreement between clinical observation and an objective method for verifying tongue cupping.

Another item that is hard to measure is the maintenance of the rhythm of sucking and pause. This has already been mentioned in other interrater reliability studies of sucking behavior at the mother's breast (Nyqvist et al., 1996). Filming the infant's behavior or surface electromyography is considered as the most objective way of measuring this item (Nyqvist et al., 1991).

These records allow two or more observers to check sucking behavior monitored minute per minute. Surface electromyography verifies muscle activity at the time of sucking (Nyqvist et al., 2001). In this case, the clinical observation of the infants' behavior also needs to be validated through an objective exam.

Scores for the presence of stress signs were also unsatisfactory. This result is probably due to changes in the infant's clinical stability, caused by the child's manipulation during the assessment. For future studies, we suggest infant monitoring to obtain objective parameters, although it is not known yet what exact parameters can be expected during oral feeding (Thoyre, 2003).

\section{Conclusion}

In general, the scale items presented adequate reliability interrater reliability. There is no sufficient evidence yet to permanently exclude those items with unsatisfactory reliability, that is, tongue cupping, maintenance of rhythm of sucking and pause and stress signs. We recommend other reliability studies, based on the use of this scale, by other health professionals active in premature care at neonatal units, or comparing the results of this instrument with objective methods.

The next study phase is the application of the scale in clinical practice to establish sensitivity and specificity levels and predictive values. 


\section{Attachment}

Preterm Infant Oral Feeding Readiness Assessment Scale

Date:

Identification:

Name: Patient File No:

Birth Date:

Postnatal age: Gestational age:

Corrected gestational age

Tube feeding: ( ) Yes ( ) No ( ) Nasogastric

( ) Orogastric Volume: $\mathrm{ml}$

Corrected Gestacional Age (2) 34 weeks or more (1) between 32 and 34 weeks (0) 32 weeks or less

Behavioral Organization
Behavioral state
(2) alert
Global posture
(2) flexed
(1) drowsy
(1) partly flexed
(0) sleep
Global tonus
(2) normotonia
(0) hypertonia
(0) extended
(0) hypotonia

Oral Posture

Lips posture

Tongue posture

(2) closed

(1) half-open

(0) open

Oral Reflexes

Rooting reflex

Sucking reflex

(2) flat

(0) elevated

(0) retracted

(0) protruded

Biting reflex

(2) present

(2) present

(2) present

(1) weak

(1) weak

Gag reflex

(2) present

(1) exacerbated presence

(1) present in anterior region

(0) absent

(0) absent

(0) absent

Nonnutritive Sucking (The test should take 1 minute)
Tongue movement
(2) adequate
(1) altered
(0) absent
Tongue cupping
(2) present
(0) absent
Jaw movemen
(2) adequate
(1) altered
(0) absent
Sucking strain
(2) strain
(1) weak
(0) absent
Sucking and pause
(2) 5 to 8
(1) $>8$
(0) $<5$
Maintenance of rhythm
Maintenance of alert state
(2) rhythmic
(1) arrhythmic
(1) partial (0) no
Stress signs
(2) yes
(1) up to 3
Saliva accumulation
( ) absent
(0) more than 3
Nose wings trembling
( ) present
Skin color changes
( ) absent ( ) present
Apnea
Tonus variation
Posture variation
( ) absent ( ) present
( ) absent ( ) present
( ) absent ( ) present
( ) absent ( ) present
Tongue or jaw tremors $\quad$ ( ) absent ( ) present
Hiccupping ( ) absent ( ) present
Crying
( ) absent ( ) present

Score:

Maximum score: 36

Instruction Guide - Preterm Infant Oral Feeding Readiness Assessment Scale

CORRECTED GESTATIONAL AGE (gestational age - Ballard plus postnatal age)

.32 weeks or less.

Between 32 and 34 weeks.

34 weeks or more.

BEHAVIORAL ORGANIZATION

Behavioral state

. Alert: eyes open and shining, responsive to stimulation, some spontaneous activity.

. Drowsy: eyes open and close, confused and dull look, takes time to respond to stimulation, varied spontaneous activity.

Sleep: eyes closed, non-responsive to stimulation; no motor activity.

Global Posture

. Flexed: flexed upper and lower limbs and neck position in median line in relation to trunk.

. Partly flexed: flexed lower limbs and neck position in median line in relation to trunk.

. Extended: upper and lower limbs and neck extended in relation to trunk.

Global tonus (parameter considered according to what is expected for preterm infant's maturity)

. Normotonic: light resistance to passive flexion and extension movements, slightly stronger in the latter.

Hypertonic: increased resistance to passive flexion and extension movements. 
Hypotonic: decreased resistance to passive flexion and extension movements.

ORAL POSTURE

Lips posture

. Closed: upper and lower lip side by side.

. Half-open: upper and lower lip partially separated.

. Open: upper and lower lip totally separated.

Tongue posture (observed by lowering the lower lip and, if necessary, the jaw)

. Flat: tongue in flat position inside oral cavity, with a rounded tip.

Elevated: tip of the tongue in elevated position, pressing the palate.

Retracted: tongue in retracted position in the oral cavity.

Protruded: tongue in protruded position in the oral cavity, beyond labial border.

ORAL REFLEXES

Rooting reflex

. Present: when four main points are stimulated in the perioral region, immediately seeks stimulated region, directing the head towards the stimulus and/or opening the mouth.

. Weak: when four main points are stimulated in the perioral region, slowly seeks the stimulated region, directing the head towards the stimulus and/or opening the mouth.

. Absent: absence of response.

Sucking reflex

Present: readily sucks own hand or examiner's gloved finger.

Weak: takes some time to start sucking own hand or examiner's finger.

Absent: absence of response.

Biting reflex

. Present: responds to stimulus exerted by the examiner's finger in the gingival line of the oral cavity by jaw clenching, followed by relaxing.

. Exacerbated presence: responds to stimulus exerted by examiner's finger in the gingival line of the oral cavity, maintaining jaw clenching.

Absent: absence of response.

Gag reflex

. Present: responds to stimulus exerted by introduction of examiner's finger by nauseas and/or vomiting when reaching the middle-posterior tongue region.

. Present in anterior region: already responds to stimulus exerted by introduction of examiner's finger by nauseas or vomiting when reaching the anterior tongue region.

. Absent: absence of response.

\section{NONNUTRITIVE SUCKING}

Tongue movement

. Normal: intraoral stimulus generates anterior-posterior and coordinated tongue movement.

- Altered: intraoral stimulus generates posterior-anterior or uncoordinated movement.

. Absent: absence of movement.

Tongue cupping

- Present: elevated tongue sides and presence of groove in central tongue region.

. Absent: absence of response.

Jaw movement

Normal: reduced jaw excursion, rhythmic and spontaneous jaw movement.

. Altered: wide jaw excursion and/or arrhythmic jaw movement and/or jaw clenching.

Absent: absence of movement.

Sucking strain

- Strain: strain compression against palate and negative intraoral pressure with resistance to withdrawal of examiner's finger from oral cavity.

. Weak: weak compression against palate and negative intraoral pressure without resistance to withdrawal of examiner's finger from oral cavity.

- Absent: absence of response.

Sucking and pause (Use the average obtained in three groups of suck/pause)

. Between 5 and 8 sucks per respiratory pause.

. More than 8 sucks per respiratory pause.

Less than 5 sucks per respiratory pause.

Maintenance of rhythm of sucking and pause (Use the number of sucks/pause obtained in three groups of suck/pause and verify if this number varied between set intervals)

. Rhythmic: maintains the number of sucks per pause expected in one and the same interval (less than 5 , between 5 and 8 or more than 8 sucks per pause).

. Arrhythmic: changes the number of sucks per pause between intervals (less than 5 , between 5 and 8 or more than 8 sucks per pause).

. Absent: absence of sucking.

Maintenance of alert state

. Yes: continues alert throughout the nonnutritive sucking test.

- Partial: continues alert only at beginning or end of nonnutritive sucking test.

. No: does not continue alert during the nonnutritive sucking test.

Stress signs 


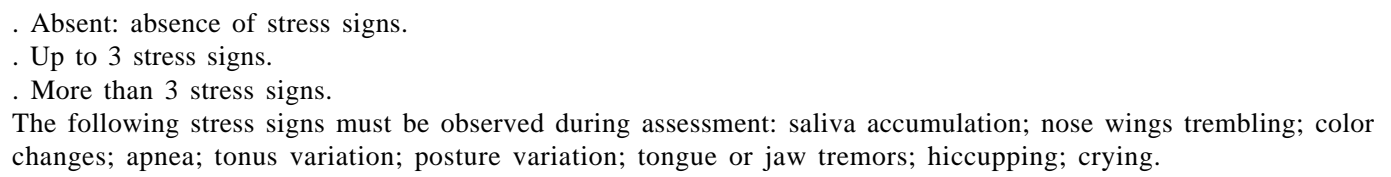

\section{References}

ANDRADE, I. S. N.; GUEDES, Z. C. F. Sucção do recémnascido prematuro: comparação do método Mãe-Canguru com cuidados tradicionais. R. Bras. Saúde Mat.-Infant., Recife, v. 5, n. 1, p. 61-69, jan.-mar. 2005.

BALlARD, J. L.; NOVAK, K. K.; DRIVER, M. A simplified score for assessment of fital maturatation of newborn infant. J. Pediatr., v. 95, n. 5, p. 769-774, nov. 1979.

BU'LOCK, F.; WOOLRIDGE, M. W.; BAUM, J. D. Development of co-ordination of suckling, swallowing and breathing: ultrasound study of term and preterm infants. Develop. Med. Child Neurol., v. 32, p. 669-678, aug. 1990.

BYERS, J. Components of developmental care and the evidence for their use en the NICU. Mat. Child Nurs., v. 28, n. 3, p. 174-180, may-jun. 2003.

CAETANO, L. C.; FUJINAGA, C. I.; SCOCHI, C. G. S. Sucção não-nutritiva em bebês prematuros: estudo bibliográfico. R. Lat.-Am. Enf., Ribeirão Preto, v. 11, n. 2, p. 232-236, mar. 2003.

DELGADO, S. E.; HALPERN, R. Amamentação de prematuros com menos de 1500 gramas: funcionamento motor-oral e apego. Pró-Fono R. Atual. Cient., Barueri (SP), v. 17, n. 2, p. 141-152, maio-ago. 2005.

FLEISS, J. L. The mensurement of interrater agreement. In: Statistical methodos for rates and proportions. New York: Jonh Wiley \& Songs Inc., 1981. p. 212-236.

FONSECA, L. M. M.; SCOCHI, C. G. S.; ROCHA, S. M. M.; LEITE, A. M. Cartilha educativa para orientação materna sobre os cuidados com o bebê prematuro. R. Lat.Am. Enf., Ribeirão Preto, v. 12, n. 1, p. 65-75, fev. 2004.

FUJINAGA, C. I. Prontidão do prematuro para início da alimentação oral: proposta de um instrumento de avaliação. 2002. 107 f. Dissertação (Mestrado em Saúde Pública) - Escola de Enfermagem de Ribeirão Preto, Universidade de São Paulo, Ribeirão Preto.

FUJINAGA, C. I. Prontidão do prematuro para início da alimentação oral: confiabilidade e validação clínica de um instrumento de avaliação. 2005. 120 f. Tese (Doutorado em Saúde Pública) - Escola de Enfermagem de Ribeirão Preto, Universidade de São Paulo, Ribeirão Preto.

HOWARD, C. R.; LANPHEAR, B. P.; DEBLIECK, E. A.; LAWRENCE, R. A. Randomized clinical trial of pacifer use and bottle-feeding or cupfeeding and their effect on breastfeeding. Pediatr., v. 3, n. 111, p. 511-518, mar. 2003.

LAU, C.; SMITH, E. O.; SCHANLER, R. J. Coordenation of suck-swallow and swallow respiration in preterm infants. Acta Paediatr., v. 92, n. 6, p.721-727, jun. 2003.

MILLER, J. L.; KANG, S. M. Preliminary ultrasound observation of lingual movement patterns during nutritive versus non-nutritive sucking in a premature infant. Dyspha., v. 22, n. 2, p. 150-160, apr. 2007.
Miller, J. L.; SONIES, B. C.; MACEDONIA, C. Emergence of oropharyngeal, laryngeal and swallowing activity in the developing fetal upper aerodigestive tract: an ultrasound evaluation. Early Hum. Develop., v. 71, n. 1, p. 61-87, feb. 2003.

NASCIMENTO, M. B. R.; ISSLER, H. Breastfeeding: making the difference in the development, health and nutrition of term and preterm newborns. R. Hosp. Clín., São Paulo, v. 58, n. 1, p. 49-60, 2003.

NASCIMENTO, M. B. R.; ISSLER, H. Aleitamento materno em prematuros: manejo clínico hospitalar. J. Pediatr., Rio de Jnaeiro, v. 80, n. 5, p. S163-S172, nov. 2004.

NEIVA, F. C. B.; LEONE, C. R. Sucção em recém-nascidos pré-termo e estimulação da sucção. Pró-fono R. Atual. Cient., Barueri (SP), v. 18, n. 2, p. 141-150, maio-ago. 2006.

NYQVIST, K. H.; FÄRNSTRAND, C.; EEG-OLOFSSON, E. K.; EWALD, K. U. Early oral behaviour in preterm infants during breastfeeding: an electromyographic study. Acta Paediatr., v. 90, n. 6, p. 658-663, jun. 2001.

NYQVIST, K. H.; RUBERTSSON, C.; EWALD, U.; SJÖDÉN, P. O. Development of the preterm infant breastfeeding behavior scale: a study of nurse-mother agreement. J. Hum. Lacta., v. 12, n. 3, p. 207-218, sep. 1996.

PALMER, M. M. Identification and management of the transitional suck pattern in premature infants. J. Perinat. Neonat. Nurs., v. 1, n. 7, p. 66-75, jun. 1993.

PINELli, J.; SYMINGTON, A.; CILISKA, P. Nonnutritive sucking in high-risk infants: benign intervention or legitimate therapy? J. Obst. Gynecol. Neonat. Nurs., v. 31, n. 5, p. 582-591, sep.-out. 2002.

ROCHA, N. M. N.; MARTINEZ, F. E.; JORGE, S. M. Cup or bottle for preterm infants: effects on oxygen saturation, weigh gain, and breastfeeding. J. Hum. Lacta., n. 18, p. 132-138, 2002.

SANCHES, M. T. C. Manejo clínico das disfunções orais na amamentação. J. Pediatr., Rio de Janeiro, v. 80, n. 5, p. S155-S162, nov. 2004.

SCOCHI, C. G. S.; KOKUDAY, M. L. P.; RIUL, M. J. S.; ROSSANEZ, L. S. S.; FONSECA, L. M. M.; LEITE, A. M. Incentivando o vínculo mãe-filho em situação de prematuridade: as intervenções de enfermagem no Hospital de Clínicas de Ribeirão Preto. R. Lat.-Am. Enf., Ribeirão Preto, v. 11, n. 4, p. 539-543, ago. 2003.

SERRA, S. O. A.; SCOCHI, C. G. S. Dificuldades maternas no processo de aleitamento materno de prematuros em uma UTI neonatal. R. Lat.-Am. Enf., Ribeirão Preto, v. 12, n. 4, p. 597-605, ago. 2004.

THOYRE, S. M. Developmental transition from gavage to oral feeding en the preterm infant. Annual Review Nurs. Res., New York, n. 21, p. 21-61, 2003.

THOYRE, S. M.; SHAKER, C. S.; PRIDHAM, K. F. The early feeding skills assessment for preterm infants. Neonat. Network, v. 24, n. 3, p. 7-16, may-jun. 2005. 